\title{
Musculoskeletal labour overload study on nursing professionals: thermography as an ergonomic diagnostic mean
}

\section{Introduction}

Nursing professionals during treatment and care of patients perform long journeys of work and are subjected daily to a mental and physical overload. On the field of healthcare nursing is not only insalubrious but also difficult, arduous and repetitive which causes physical injuries that may be irreversible. ${ }^{1}$ The constant overload, result of inadequate posture and repetitive labor gestures that degenerates body segments are responsible for musculoskeletal injuries that produces pain, temporary and/or permanent disability and reduced life quality for the laborer. ${ }^{2}$ Considering the indispensable work accomplished by the nursing team, it was sought by ergonomic evaluation methodology means to characterize overloads suffered during the nursing professional activities.

\section{Objetive}

The study proposal was to identify by ergonomics evaluation the labor overload on most demanded body segments, to rate pain intensity on laborers and to diagnose physical overload using thermography as a tool to verify labor overload on nursing professionals.

\section{Materials and methods}

For such was adopted the descriptive exploratory model of transversal cut, ${ }^{3}$ where the study population was composed by individuals from the Psychiatric Institute of Santa Catarina State (IPq/ SC) nursing team, on the period between August and September of 2014. The group was composed by 39 subjects from both genders, with ages between 30 to 50 years selected randomly. It was elected as inclusion criteria the subjects that were active workers from IPq/ $\mathrm{SC}$ nursing team. As exclusion criteria, professionals working at administrative and manager positions and; or who are removed from

\author{
Volume 3 Issue 2 - 2018
}

\author{
Giuliano Mannrich,' Marina Tillmann, ${ }^{2}$ \\ Marcos A Godinho, ${ }^{3}$ Gisele Locks, ${ }^{3}$ Eugênio \\ Andrés Días Merino' \\ 'Federal University of Santa Catarina, Brazil \\ ${ }^{2}$ Psychiatric Institute of Santa Catarina State, Brazil \\ ${ }^{3}$ Institute of Superior Education in Florianópolis, Brazil
}

Correspondence: Giuliano Mannrich, Physiotherapist of Figueirense Futebol Clube, Professor of Estácio de Sá, Florianópolis, Federal University of Santa Catarina, Brazil, Email gmannrich@gmail.com

Received: November 24, 2017 | Published: March 05, 2018 work or at retirement process and medical leave.

To the accomplishment of the present work, initially it was signed a Term of Free and Enlightened Consent- TFEC, later was performed a semi-structured interview for group characterization. After that it was applied the Nordic Questionnaire of Musculoskeletal SymptomsNQMS. ${ }^{4}$ To quantify the pain intensity it was applied the Visual Analogical Scale-VAS. Finally, laborers presenting pain above level 7 from VAS were selected and a thermographic record was performed before and after labor effort on the body segment most stricken by pain. ${ }^{5}$ To analyze the data were used Mean and standard deviation, percentile distribution, graphs and tables using MS Excel 2011. For thermal variation significance determination was applied the T-student test and later the ANOVA test using SPSS program ${ }^{6}$ (Figure 1).

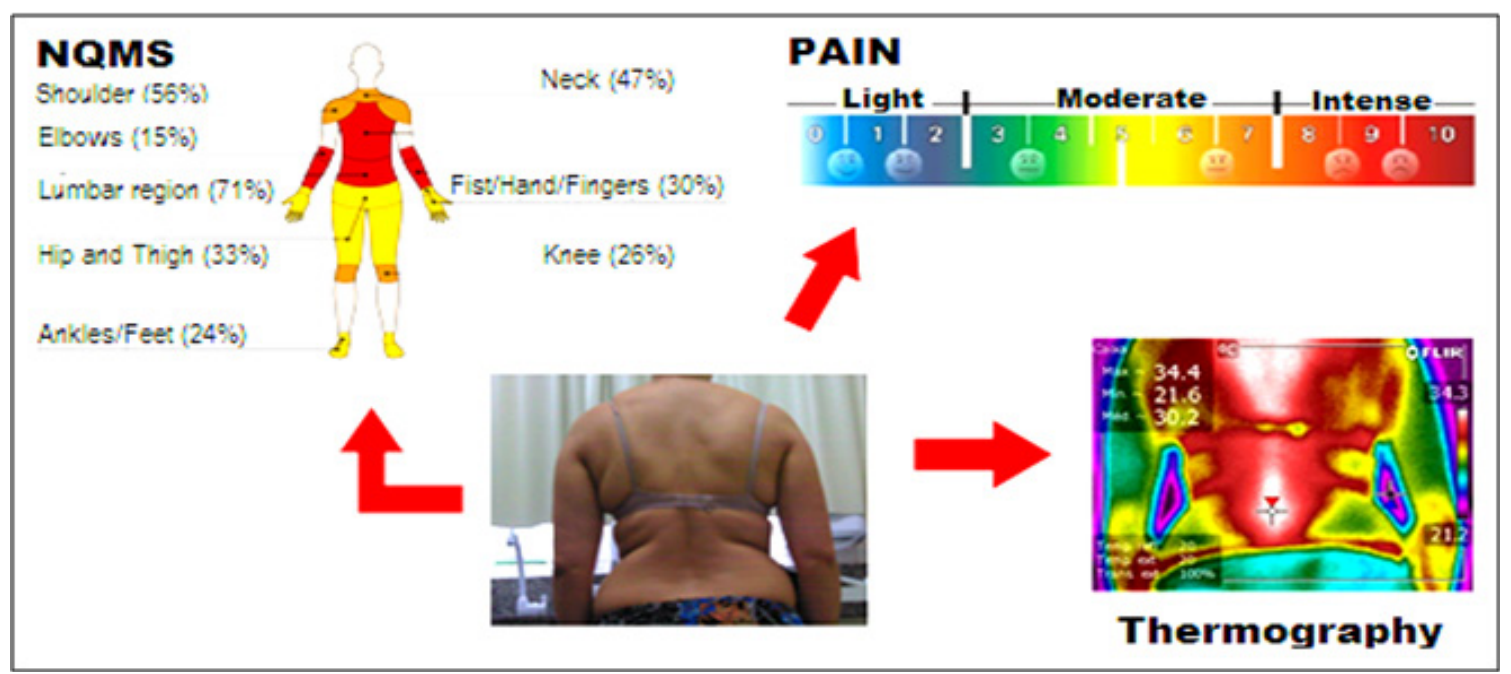

Figure I Data collection sequence: I, NQMS; 2,VAS (PAIN); 3,THERMOGRAPHY. 


\section{Results}

It was observed as results high physical labor overload indices, affecting $82 \%$ of nursing professionals where $47 \%$ of the subjects reported intense pain that limitates work (Figure 2).

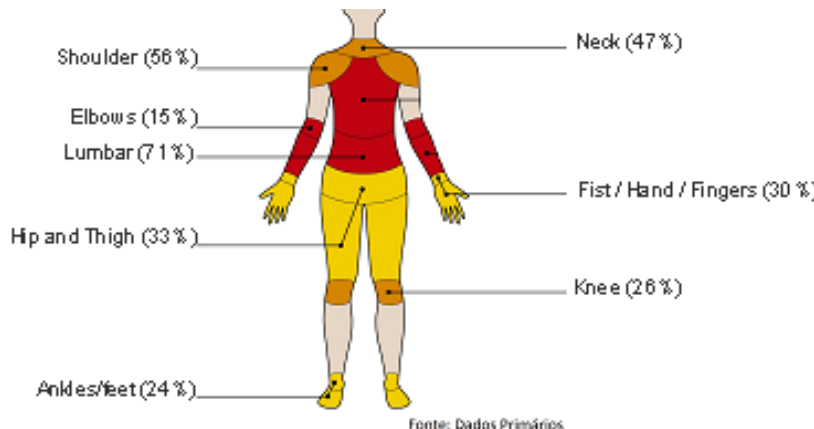

Records from NQMS affirmed that the main body regions stricken by pain e limitation were: lumbar $71 \%$, shoulders $56 \%$ and neck $47 \%$. Pain intensity registered by VAS was $17.6 \%$ of light pain, $52.9 \%$ of moderate pain and $29.4 \%$ of intense and limiting pain respectively (Table 1).

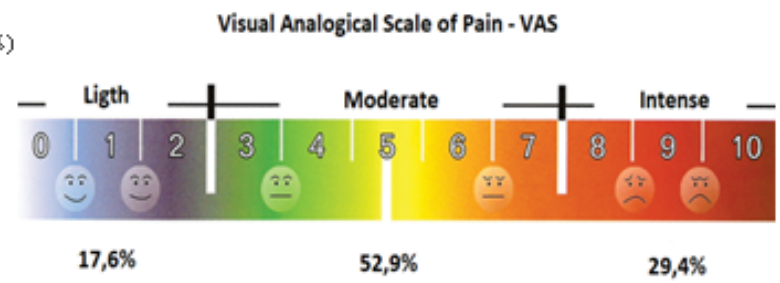

Figure 2 Distribution of pain by the Nordic Questionnaire of Musculoskeletal Symptoms (NQMS) and Analogical Visual Scale (AVS).

Table I Analysis of Temperature (thermographic) variation of the lumbar spine of workers with severe pain

\begin{tabular}{lll}
\hline & $\mathbf{T 1}\left({ }^{\circ} \mathbf{C}\right)$ & $\mathbf{T 1}\left({ }^{\circ} \mathbf{C}\right)$ \\
\hline 1 & 35.1 & 35.5 \\
2 & 35.1 & 35.1 \\
3 & 35.4 & 35.8 \\
4 & 35 & 35.2 \\
5 & 34.7 & 35.3 \\
6 & 33.5 & 34.7 \\
7 & 35 & 35.4 \\
8 & 34.4 & 35.4 \\
9 & 35 & 35.7 \\
10 & 33.8 & 34.9 \\
11 & 35.4 & 35.8 \\
12 & 33.5 & 34.7 \\
13 & 35 & 35.7 \\
14 & 34.7 & 35.3 \\
\hline
\end{tabular}

TI, initial temperature $\left(\mathrm{C}^{\circ}\right) ; \mathrm{TF}$, final temperature $\left(\mathrm{C}^{\circ}\right)$

On thermographic records from 14 nursing professionals (with pain above level 7 at VAS) were found an average of the superficial body temperature, at lumbar region, of $34.7^{\circ} \mathrm{C}$ before labor effort and $35.4^{\circ} \mathrm{C}$ after labor effort, being the significant variation $(\mathrm{p} \leq 0,037)$, diagnosing the physical overload at lumbar spine for these labor effort, which comply with the subjective reports of lumbar pain on $\mathrm{IPq} / \mathrm{SC}$ nursing professionals.

\section{Conclusion}

The study evidences that nursing professionals are exposed to a high risk on developing labor diseases, showing an urgent and immediate need of ergonomic compliance for these professionals that take care of everyone health and are not remembered from the health and lifequality preventive programs perspective. This is verified by the high incidence of pain and musculoskeletal injuries referred on instruments, and confirmed by the thermographic diagnostic. New studies are suggested associating thermography to the electromyographic record on labor effort overloaded muscular groups.

\section{Acknoweledgements}

None.

\section{Conflict of interest}

Authors declare that there are no conflicts of interest.

\section{References}

1. Rosa FA, Garcia PA, Vedoato T, et al. Incidência de LER/DORT em trabalhadores de enfermagem (Repetitive Effort Injuries on Nursing laborers). Acta Sci Health Sci. 2008;30(1):19-25.

2. Fernades JS, Miranzi SSC, Iwamoto HH, et al. Qualidade de vida dos enfermeiros das equipes de saúde da família: a relação das variáveis sociodemográficas (Family Health Nursing team Life-Quality). Texto contexto-enferm Set. 2010;19 (3):434-442.

3. Gil, Antônio Carlos, Como Elaborar Projetos de Pesquisa (How to Develop Research Projects). In: lakatos, EM, Marconi MA. Fundamentos de metodológica científica. São Paulo: Atlas; 1993.

4. Pinheiro FA, Tróccoli BT, Carvalho CC. Validação do Questionário Nórdico de Sintomas Osteomusculares como medida de morbidade (Nordic Questionnaire of Musculoskeletal Symptoms Validation). Revista de Saúde Pública. 2002;36(3):307-312.

5. Caldwell, Marc C, Ram CP, et al. Diagnosis of lumbosacral diskospondylosis in a bucking bull assisted by high definition thermal and nuclear scintigraphic imaging. Journal of the American Veterinary Medical Association. 2017;250(5):554-560.

6. www.previdencia.gov.br 